\title{
OBITUARY
}

\section{Mr. W. M. BEAUMONT}

WE regret to record the sudden death on October 18, of $\mathrm{Mr}$. W. M. BEAUMONT, of Bath. He was at work in his consulting room, seeing a patient, at the time.

William Mardon Beaumont was born in 1851. He was educated at Aberdeen and at the Middlesex Hospital, where he was housesurgeon to Mr. J. W. Hulke. He had taken the usual double qualification of an earlier day, namely the L.S.A. in 1874, and the M.R.C.S. in the next year. Settling in Bath he devoted himself to ophthalmology, and was Hon. Surgeon to the Bath Eye Infirmary from 1888 to 1908 . He joined the Ophthalmological Society of the United Kingdom forty years ago, and at one time acted as one of its Vice-Presidents.

Beaumont was an active member of the ophthalmic section of the British Medical Association; thus, he was Secretary of the section at the Carlisle meeting in 1896, a Vice-President at the Leicester meeting in 1905; and when, three years ago, the Association held its annual meeting at Bath, he was President of the section, a fitting tribute to his position as the senior ophthalmic surgeon practising in the city of his adoption.

He contributed papers on subjects of ophthalmic interest to the various journals; wrote a good deal on the subject of malingering in eye cases, and was the author of a small book on industrial eye injuries and the Workmen's Compensation Act which was published in 1907.

Apart from his work, he was a keen collector of furniture and pottery, and was fond of antiquarian pursuits.

\section{NOTE}

WE regret to have to record the recent death of Death Sir Hugh Anderson, Master of Gonville and Caius College, Cambridge, who was the first to demonstrate beyond dispute, by physiological means, the existence of a dilatator iridis. 


\section{FUTURE ARRANGEMENTS}

1928

December 7.- North of England Ophthalmological Society, at Leeds.

December 14.-Section of Ophthalmology, Royal Society of Medicine. (Clinical Meeting).

\section{9}

January 11.-Section of Ophthalmology, Royal Society of Medicine.

February 1.-North of England Ophthalmological Society, at Liverpool.

February 8.-Sertion of Ophthalmology, Royal Society of Medicine.

March 1.-North of England Ophthalmological Society, at Newcastle-on-'Tyne.

March 8.-Section of Ophthalmology, Royal Society of Medicine. (Clinical Meeting).

March 22.-North of England Ophthalmological Society, at Sheffield.

June 14.-Section of Ophthalmology, Royal Society of Medicine. (Annual Meeting).

September :-International Congress of Ophthalmology at Amsterdam.

\section{CONTEMPORARY OPHTHALMIC LITERATURE}

American Journal of Ophthalmology. October, 1928.

BARKAN, OtTo and HANS. Fracture of the optic canal.

CORBETT, J. J. Plastic dacryorhinostomy.

SCARLETT, HUNTER W. Ptosis operation according to the Shoemaker method:

WILDE, A. Congenital absence of abduction.

VAIL, DERRICK T., Jr. Argyrosis of the tarsal conjunctiva in an infant.

BlaCk, N. M., and HAEssler, F. HERBERT. Pigmented lesions of the conjunctiva.

PISCHEl, Kaspar. Glaucoma, an historical review.

ALLEN, KENNETH D. A. X-ray therapy as a diagnostic agent in orbital tumors.

CRISP, WILliam H. The literary phase of ophthalmology.

The Journal of Ophthalmology, Otology and Laryngology. August, 1928.

THOMPSON, LE Roy. Industrial ophthalmology. 
September, 1928.

WARNER, CARDEN F. Hyperplastic sphenoiditis and its clinical relation to the eye. BOWMAN, STUART H. Report of a case of ethmoiditis with orbital complications. Paganelli, T, R. Pseudo-glioma in a child of five weeks.

Annales d'Oculistique. September, 1928.

REDSLOB and REIss. Contribution to the study of swelling of the vitreous. The rôle of $\mathrm{pH}$.

AMSLER and DUBOIS. Ophthalmoscopic topography and retinal detachment.

SOBHY BEY. Palpebro-conjunctival bilharziosis.

$$
\text { October, } 1928 .
$$

DiAz-CANEJA. On binocular alternation.

Winckler Prins. Study of the bands of illumination of the cornea and of the deposit of gold in scars.

DE ST. MARTIN. Adrenalin mydriasis in the operation for cataract.

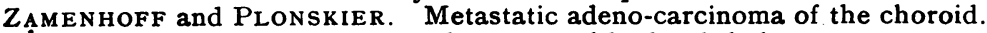

CosmetTatos. On the genesis of congenital hydrophthalmos.

Archives d'Ophtalmologie. September, 1928.

WEEKERS and MissotTEn. Does amaurosis gravidarum, wrongly named uraemic amaurosis, necessitate termination of pregnancy?

GONIN. My most recent experience in retinal detachment.

DEJEAN. Pseudo-ossification of the vitreous and proliferating osteogenetic cyclochoroiditis.

Bistis. Experimental and clinical study of the rôle of the sympathetic in the aetiology of heterochromia:

\section{October, 1928.}

COPPEZ. On chalky deposits in the eye.

TRANTAS. On gonioscopy.

WEEKERS. A proposal concerning the physical fitness of motor drivers

JEANDELIZE. On the necessary visual acuity of motorists.

\section{La Clinique Ophtalmologique. July, 1928.}

MONBRUN. Cure of trachoma by surgical diathermy.

DOMEC. Milk in therapeutics.

NATTAF. History of vaccine therapy in general, with special reference to gonococcal ophthalmia.

\section{Archiv für Ophthalmologie. October, 1928.}

SERR. On the question of the causal relation between pupillary diameter and intra-ocular tension.

BODENHEIMER and KORBSCH. Clinical and anatomical observations on the theory of pupillary fibres.

BÜCKLERS. Experimental and histological investigation of the influence of highly concentrated ultra-violet light on the rabbit's eye.

Oнм. On nystagmus.

SAFAR. On the appearance of rings in the iris, due to its wrinkling in conditions of marked softening of the eye.

Magnus. Dacryops with anophthalmos.

JAENSCH. Paresis of the superior rectus.

HEDINGER. Mariotte's spot in axial myopia.

GAISER. The double refracting lens.

CORDS. After images of movement.

KEstenbaum and EIDELBERG. Convergence reaction of the pupil and accommodation.

LEIRI. Is there an extra-lenticular accommodation mechanism ?

MAGNUS. Radiography of pituitary tumours with notes on the hemianopic pupil.

KUMER and SALLMANN. On iris discoloration after radium. 
Klinische Monatsblätter für Augenheilkunde. October, 1928.

Marx, MEndes da Costa-Vet, NaAR, AND Wolff. New method of using cocaine in ophthalmology.

Meyerbach. Corodenine as a protective of the eye from ultra-violet light.

UYEMURA. On a noteworthy fundus change in two cases of idiopathic hemeralopia.

WEIHMAN. Natural size photography of the eye.

VAJDA. The avoidance of the sequelae of eve injuries, with reference to the workman's insurance.

TABORISKY. On the aetiology of epitarsus.

KoYANAGI. Further observations on the occurrence of cupped disc in nonglaucomatous eyes.

\section{Zeitschrift für Augenheilkunde. October, 1928.}

LIEBERMANN. On muscle lengthening.

UTERMANN. On statistics of blindness in large towns.

MORETTI, On appearance of bone inside a glaucoma cup.

KREUTZFELDT. Notes on hypopyon iritis.

GLASSCHIEB. On the pathogenesis and clinical course of retro-bulbar neuritis.

\section{Annali di Ottalmologia e Clinica Oculistica. October, 1928.}

Ovio. Formulae and tables of incapacity from ocular injuries.

MihelatTi. The normal pressure of the cerebro-spinal fluid.

LUPPINO. Cavernous angioma of the orbit.

ANTONibon. Modification of the lash follicles after electrolysis.

Giannantoni. Researches into the chemical composition of the blood in cataract patients.

\section{Archivio di Ottalmologia. August, 1928.}

GUERRA. A case of cavernous sinus thrombosis from sphenoidal sinusitis.

SGRosso. Trachoma, follicular conjunctivitis and conjunctival tubercle, a histopathological study.

\section{Bolletino d'Oculistica. August, 1928.}

SERRA. Tumours of the caruncle.

FEDERICI. On the histology of conjunctival flaps in perforating wounds of the cornea,

Aliquò-MAZZEI. Histological study of the glandular formations in the wall of the lacrimal sac.

BENCINI. On a rare form of palpebral tubercle.

\section{September, 1928.}

Cavara. On a case of sub-chronic uveal parotid fever of Heerfordt.

VERzalla. Clinical contribution to the study of neoplasms of the orbit.

COSENZA. Considerations on three cases of pathological cranio-stenosis.

MAESTRO. On a perfected method of intra-capsular extraction of senile cataract.

Archivos di Oftalmologia. October, 1928.

Ribas, Valero. On ocular dynamics.

\section{Revista Oto-Neuro-Oftalmologica y de Cirurgia Neurologica.}

VASQUEZ BARRIERE. Intra-ocular and meningeal haemorrhages.

LLAMBIAS. Histogenesis and classification of tumours of nerve tissue.

ERRECART. Nystagmus from pneumatic reactions and Babinski's electric test.

MINGAZZINI. The architecture of Lenin's cerebral hemispheres.

RICALDONI. Syndrome of the external wall of the cavernous sinus of probable syphilitic origin. 


\section{INDEX.}

\section{Original Communications and Clinical,}

\section{Pathological and Bacteriological Memoranda.}

Aynsley, T. R.-A lamp for ophthalmic work

Burnham, G. Herberı.-Remarks regarding the discussion upon the aetiology

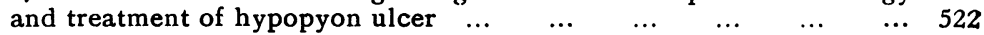

Butler, T. Harrison.-Optico-ciliary veins on the papilla $\quad \begin{array}{lllll}\ldots & \ldots & \ldots & \ldots & 522\end{array}$

Chou, C. H.-Angiopathia retinae traumatica (Purtscher) : with some remarks $\begin{array}{lllllllllll}\text { on pigment migration } & \ldots & \ldots & \ldots & \ldots & \ldots & \ldots & \ldots & \ldots & 570\end{array}$

Davenport. R. C. - The after results of cataract extraction $\quad \ldots \quad \ldots \quad \ldots \quad \ldots \quad$ • 85

$\begin{array}{lllllll}\text { Duggan, J. N.-Case of rhinosporidium Kinealyi } & \ldots & \ldots & \ldots & \ldots & \ldots & 526\end{array}$

Duke-Elder, W. Stewart. - Ultra-violet light in the treatment of ophthalmic

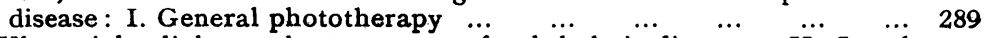
Ultra-violet light in the treatment of ophthalmic diseases : II. Local $\begin{array}{llllllllllll}\text { phototherapy } & \ldots & \ldots & \ldots & \ldots & \ldots & \ldots & \ldots & \ldots & \ldots & 353\end{array}$

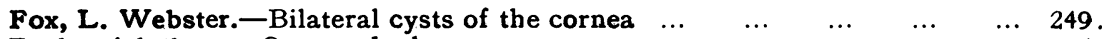
$\begin{array}{llllllll}\text { Fuchs, Adalbert.-On pseudoglaucoma } & \ldots & \ldots & \ldots & \ldots & \ldots & \ldots & 65\end{array}$

Hagedoorn, A.-The early development of the endothelium of Descemet's membrane, the cornea and anterior chamber of the eye $\quad \ldots \quad \ldots \quad 479$

Halbertsma, K. T. A., and Verryp, C. D.-Two cases of Parinaud's $\begin{array}{llllllllll}\text { conjunctivitis } & \ldots & \ldots & \ldots & \ldots & \ldots & \ldots & \ldots & \ldots & \ldots\end{array}$

Hardie, D.-Case of myasthenia gravis operated on for ptosis by $\dddot{H}$ Hess's method

Harris, S. Taylor.-Case of aneurysm of the anterior cerebral artery causing compression of the optic nerves and chiasma $\ldots \ldots \ldots$

Heal, J. G. F.-Serious haemorrhage from the conjunctiva ${ }^{\prime}$ in an infant, following instillation of silver nitrate solution $\quad \ldots \quad \begin{array}{llllll}\ldots & \ldots & \ldots & \ldots & 33\end{array}$

Henderson, E. E., and James, R. R.-A peculiar case of glaucoma $\ldots \ldots \ldots$

Hine, Montague L., and Wyatt, R. B. Hervey.-Case of neurofibromatosis of right orbit $\quad \begin{array}{lllllllllll} & \ldots & \ldots & \ldots & \ldots & \ldots & \ldots & \ldots & \ldots & \ldots\end{array}$

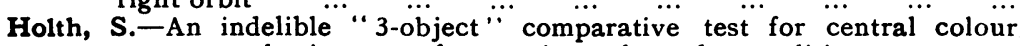
$\begin{array}{llll}\text { scotoma - also in cases of congenital colour abnormalities } & \ldots & \ldots & 309\end{array}$

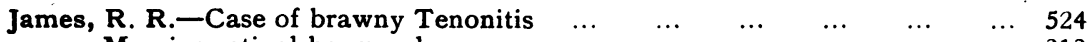
$\begin{array}{llllllllll}\text { Massive retinal haemorrhages... } & \ldots & \ldots & \ldots & \ldots & \ldots & \ldots & 313\end{array}$ $\begin{array}{lllllllll}\text { Ophthalmic leechdoms } \ldots & \ldots & \ldots & \ldots & \ldots & \ldots & \ldots & \ldots & 401\end{array}$

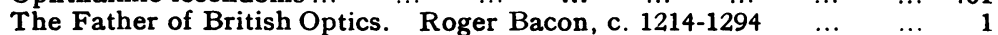

$\begin{array}{lllllllll}\text { Warner's operation for cataract } & \ldots & \ldots & \ldots & \ldots & \ldots & \ldots & 259\end{array}$

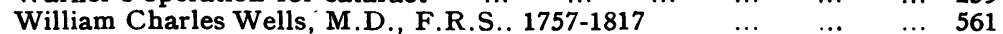
$\begin{array}{llllllllll}\text { William Coward, 1658-1725 } & \ldots & \ldots & \ldots & \ldots & \ldots & \ldots & \ldots & \ldots\end{array}$

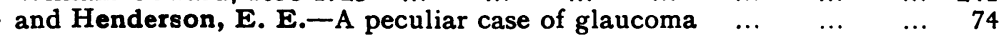


Kaul, S. N.-Ext raction of thorn from orbital cavity

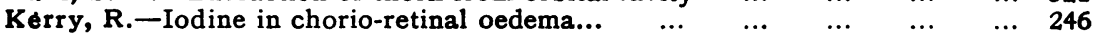

Law, Frank W.-Aseptic serous meningitis following intra-ocular foreign $\begin{array}{lllllllllllll}\text { body } & \ldots & \ldots & \ldots & \ldots & \ldots & \ldots & \ldots & \ldots & \ldots & \ldots & 644\end{array}$

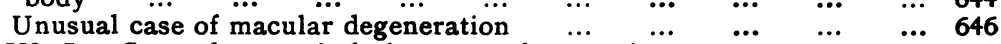

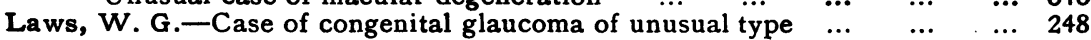

McCurry, A. L.-An examination of the fields of vision in the last weeks of $\begin{array}{lllllllllll}\text { pregnancy } & \ldots & \ldots & \ldots & \ldots & \ldots & \ldots & \ldots & \ldots & \ldots & 177\end{array}$

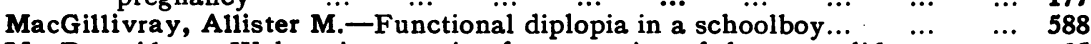

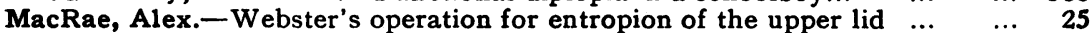

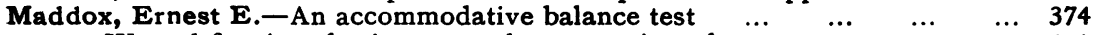

Wound-fixation, for intracapsular extraction of cataract... $\quad \ldots . \quad \ldots \quad 411$

Mann, Ida C. - The process of differentiation of the retinal layers in vertebrates 449

Paton, Leslie.-Conjunctival bridge in cataract extraction $\quad \ldots \quad \ldots \quad \ldots \quad \ldots \quad 525$

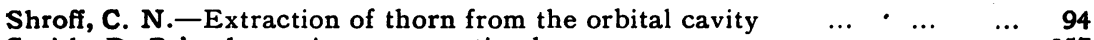

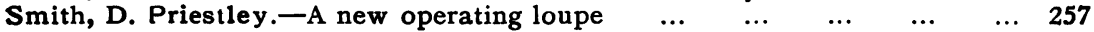

Smith Kenneth R.-Concomitant strabismus and heterophoria $\quad \ldots \quad \ldots \quad \ldots \quad 581$

Sourasky, A.-Race, sex and environment in the development of myopia $\begin{array}{llllllllll}\text { (preliminary investigation) } & \ldots & \ldots & \ldots & \ldots & \ldots & \ldots & \ldots & 197\end{array}$ The growth of the eye and the development of myopia : A study in

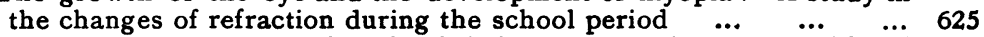

Stewart, D. Stenhouse.-A combined ophthalmoscope, retinoscope and hand $\begin{array}{lllllllllll}\text { slit-lamp } \ldots & \ldots & \ldots & \ldots & \ldots & \ldots & \ldots & \ldots & \ldots & \ldots & 519\end{array}$ Case of bilateral sphenoidal empyema with mainly ocular manifestations

Taylor, James.-Cases of ophthalmological and neurological interest...

Thomson, Ernest.-Unilateral chronic anterior uveitis in children. A clinical note $\quad \ldots \quad \ldots \quad \ldots \ldots, \ldots, \ldots$

Vernon, M. D.-Methods of recording eye movements $\quad \ldots \quad$...

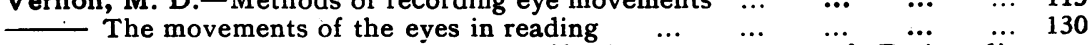

Verryp, C. D., and Halbertsma, K. T. A.- Two cases of Parinaud's $\begin{array}{lllllllllll}\text { conjunctivitis } & \ldots & \ldots & \ldots & \ldots & \ldots & \ldots & \ldots & \ldots & \ldots & 79\end{array}$

Wolf, E.-A bend in the sixth cranial nerve-and its probable significance ...

Wood, D. J.-Melanosis of the iris and new formation of a hyaline membrane

Wyatt, $R$. B. Hervey, and Hine, Montague L. $\stackrel{\cdots}{ }$ Case of neurofibromatosis $\begin{array}{llllllllllll}\text { of right orbit } & \ldots & \ldots & \ldots & \ldots & \ldots & \ldots & \ldots & \ldots & \ldots & 513\end{array}$

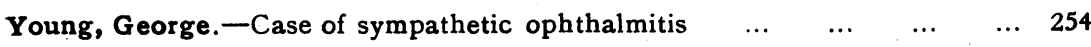




\section{Book Notices.}

Alien Menace, The (A. H. Lane), London, 1928 ...

Annual Report of Department of Health, Government of Palestine, for 1926

Clinico Oftalmológica Iconográfica Esquemática de Enfermedades y Anomalías

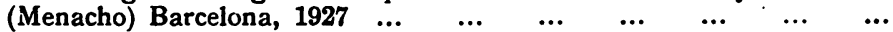

Das Auge : seine Schädigungen, ihre Verhütung und Bekämpflung (V. Hanke) Wien, $\begin{array}{llllllllll}1927 & \ldots & \ldots & \ldots & \ldots & \ldots & \ldots & \ldots & \ldots & \ldots\end{array}$

Der graue Altersstar, seine Ursachen und seine nichtoperative Behandlung

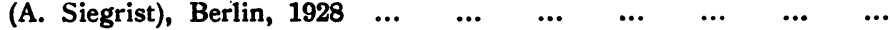

Development of the Human Eye (Ida C. Mann), Cambridge, $1928 \ldots \ldots$

Die epidemische Mangelhemeralopie (sog. Essentielle Hemeralopie). Eine Beitrag zur Lehre von den Avitaminosen (Th. Birnbacher), Berlin, 1927

Die Lichtbehandlung in der Augenheilkunde. (A. Birch-Hirschfeld and W.

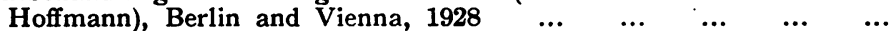

Die Mikroskopie des lebenden Auges an der Gullstrandschen spalt-lampe mit Atlas typischer Befunde (A. Meesmann), Berlin, 1927 ... $\quad \ldots \quad \ldots$

Gewerbliche Augenschädigungen und ihre Verhüten ( $O$. Thies), Berlin, 1928

Handbuch der biologischen Arbeitsmethoden, Abt. V. (E. Abderhalden),

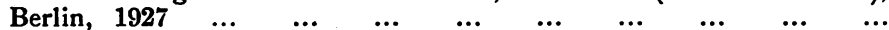

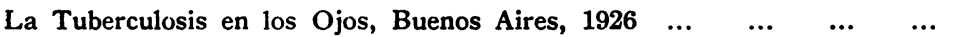

Martindale and Westcott's Extra Pharmacopoeia (W. Martindale), Nineteenth Edition, Vol. I., London $\ldots$...

Myopia : London County Council. Annual Report of the Council. Public

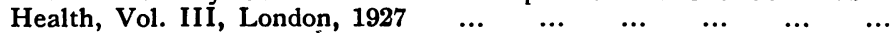

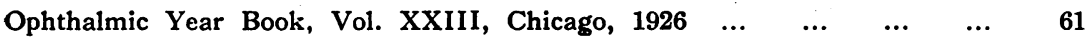

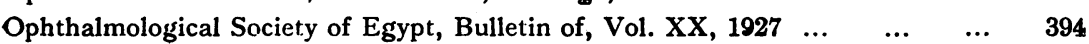

Prescribing of Spectacles (A. S. Percival), Third Edition, Bristol, $1928 \quad \ldots \quad 508$

Recent Advances in Ophthalmology (W. Stewart Duke-Elder), London, 1927

Revista Oto-Neuro-Oftalmologica y de Cirurgia Neurologica, July and August,

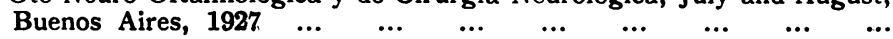

Röntgenbehandlung in der Augenheilkunde: Handbuch der Röntgentherapie, herausgegeben von Prof. Paul Krause (W. Stock), Leipzig, 1928

Sémiologie Oculaire. Statique et Dynamique Oculaires (F. Terrien), Paris, 1928

Stereoscope in Ophthalmology (D. H. Wells), Boston, $1928 \quad \ldots \quad \ldots \quad \ldots$

Strabismus. Its aetiology and treatment (O. Wilkinson), London, $1928 \ldots$

The Problem of Alien Immigration into Great Britain, illustrated by an examination of Russian and Polish Jewish Children, Part III, (Karl Pearson and Margaret Moul), Annals of Eugenics, Vol. III, $\begin{array}{llllllllll}\text { Parts } 1 \text { and } 2 & \ldots & \ldots & \ldots & \ldots & \ldots & \ldots & \ldots & \ldots & \ldots\end{array}$

Thirteenth Annual Report of Ophthalmic Section, Department of Public

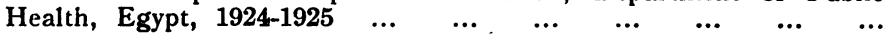

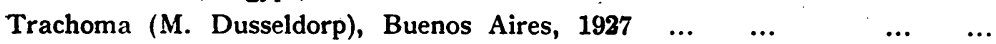

Transactions of American Ophthalmological Society, Vol. XXV, Philadelphia, $\begin{array}{cccccccccc}1927 & \ldots & \ldots & \ldots & \ldots & \ldots & \ldots & \ldots & \ldots & \ldots\end{array}$

Treatment of Cataract and some other Common Ocular Affections (H. Smith),

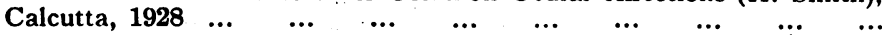

Ueber homonyme Hemianopsie (E. Bunge), Berlin, 1928 ...

Ultra-Violet Rays in the Treatment and Cure of Disease (P. Hall), London, 1927 ... 
NAMES.

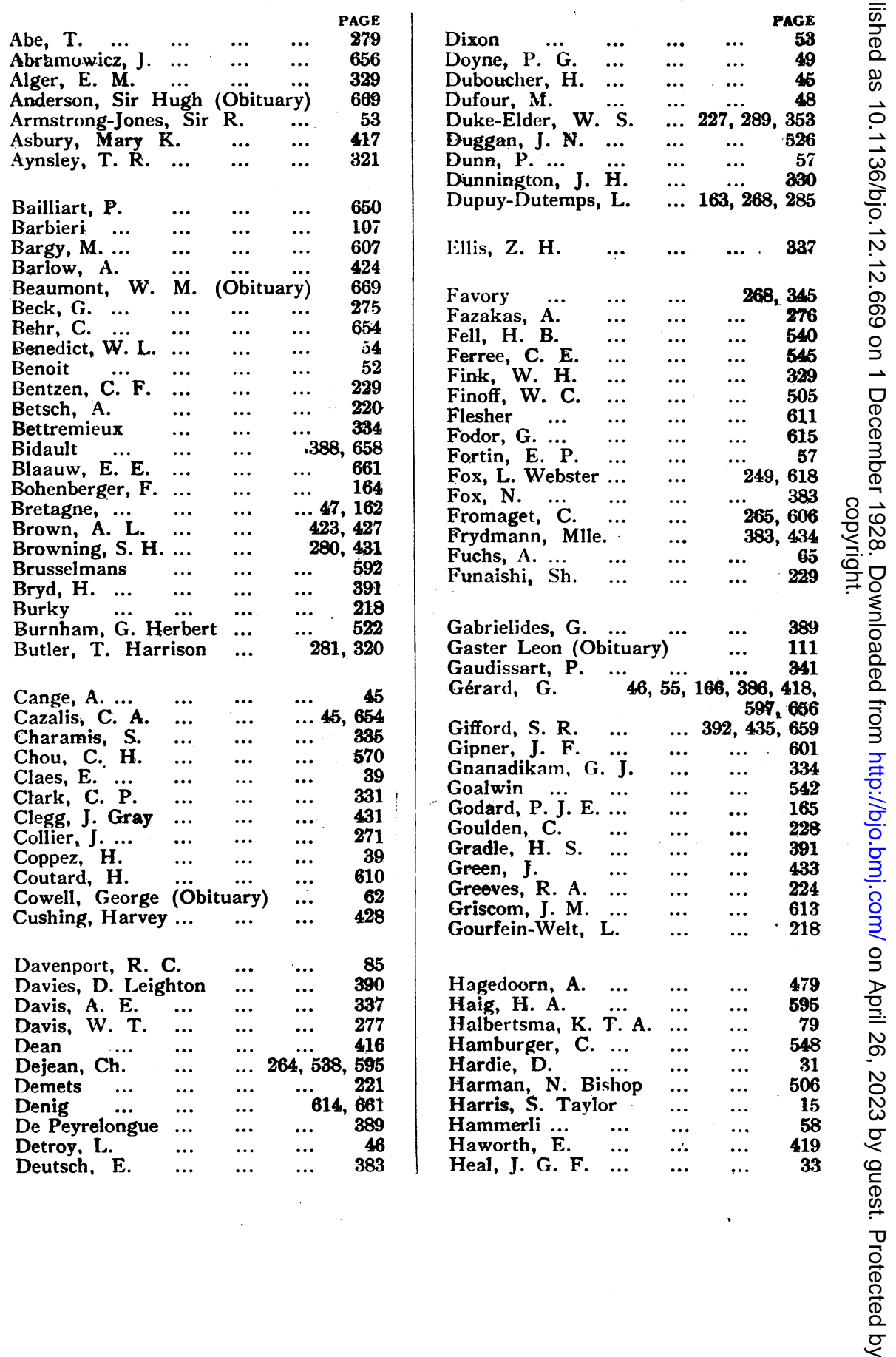




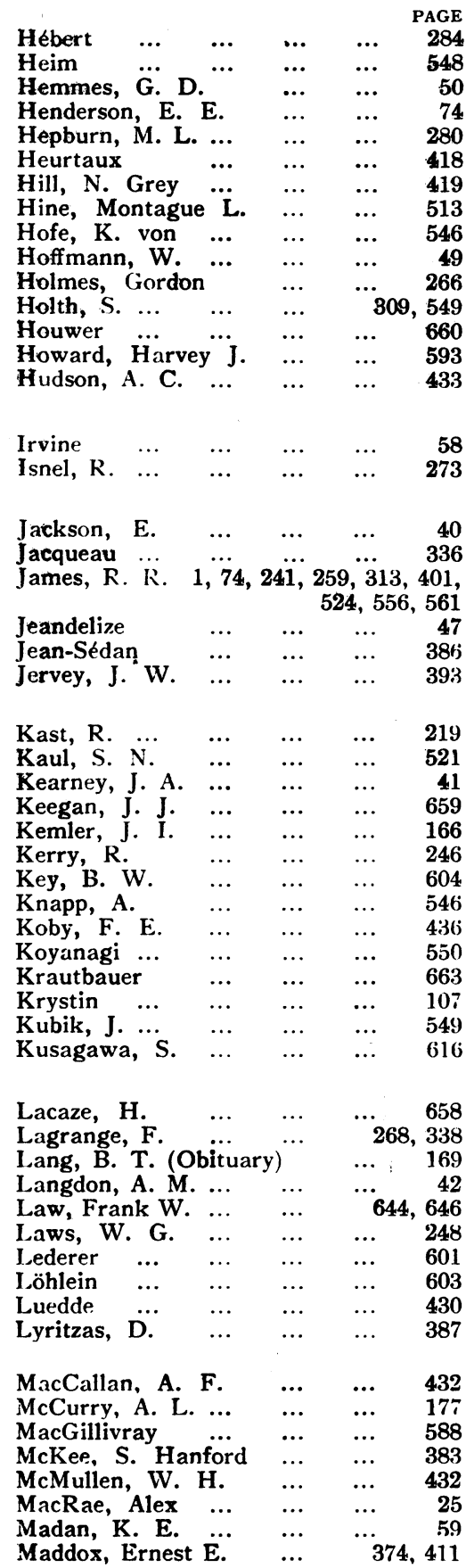

Maghraby, A. M.

$\begin{array}{llllll}\text { Maillard } & \ldots & \ldots & \ldots & \ldots & 48\end{array}$

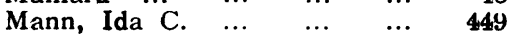

Marlow, F. M. $\quad \ldots \quad$.. $\quad \ldots . \quad 331$

di Marzio, $Q$. $\quad \ldots \quad \ldots \quad \ldots 41,426$

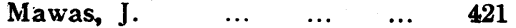

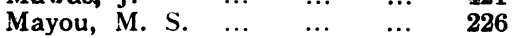

$\begin{array}{lllll}\text { de Meinicki } & \ldots & \ldots & \ldots & \mathbf{6 5 6}\end{array}$

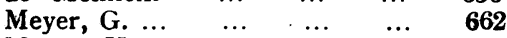

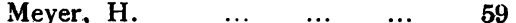

$\begin{array}{lllll}\text { Meyer, W. } & \ldots & \ldots & \ldots & 60 \\ \text { Mirimanoff } & \ldots & \ldots & \ldots & 60\end{array}$

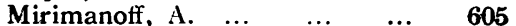

Monod, $O . \quad \ldots \quad \ldots 6 \quad \ldots \quad 610$

Morax, V. $\quad \ldots \quad \ldots . \quad 389,599$

Morel, J. ... $\quad \ldots \quad \ldots \quad 46,386,597$

Morgan, A. M. $\quad \ldots \quad$...

$\begin{array}{lllll}\text { Narog, F. } & \ldots & \ldots & \ldots & 381\end{array}$

Nickel, A. A. C. ... $\quad \ldots \quad$...

Noguchi, H. (Obituary) 98, 387, 396

Nordmann, J. ... ... . 215, 328

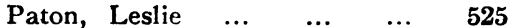

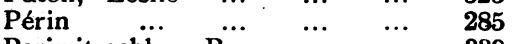

Periwitzschky, R. $\quad \ldots . \quad \ldots . \quad 339$

Pesme, P. $\quad \ldots \quad \ldots . \quad 220,224$

Pike, N. H. $\quad \ldots . \quad \ldots \quad \ldots .276$

Piotrowski, G. ... ... 218, 384, 434

$\begin{array}{llllll}\text { Posey } & \ldots & \ldots & \ldots & \ldots & 102\end{array}$

Post, M. Hayward $\ldots . \quad \ldots \quad 594$

Ramsay, A. Maitland ... $\quad 340,425$

Rand, G. ... $\quad \ldots \quad \ldots . \quad \ldots \quad 545$

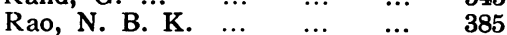

Reese, A. B. ... ... 612,613

$\begin{array}{lllll}\text { Regaud, Cl. } & \ldots & \ldots & \ldots & 610\end{array}$

Reimers, $O . \quad \ldots \quad \ldots . \quad \ldots \quad 4 \mathbf{4 2 0}$

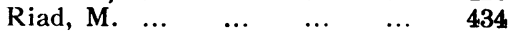

$\begin{array}{lllll}\text { Richard, G. } & \ldots & \ldots & \ldots & \mathbf{6 1 0}\end{array}$

Riddell, B. (Obituary) $\ldots . \quad \ldots .617$

$\begin{array}{lllll}\text { Ridley, F. } & \ldots & \ldots & \ldots & 532\end{array}$

Rodiet, A. .... $\quad \ldots \quad \ldots . \quad \ldots \quad 56$

Robinson, G. Allen $\ldots . \quad \ldots .609$

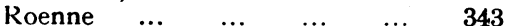

Rolleston, $\dddot{\text { Sir }}$ H. $\begin{array}{lllr}\cdots & \cdots & \cdots & 343 \\ & \cdots & \cdots & 53\end{array}$

$\begin{array}{lllll}\text { Ronne, } H . & \ldots & \ldots & \ldots & 333\end{array}$

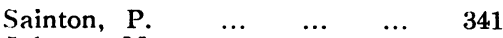

Saltane, M. $\quad \ldots \quad \ldots . \quad \ldots .656$

$\begin{array}{lllll}\text { Salvati } & \ldots & \ldots & \ldots & \ldots \\ & & \ldots & & \\ & & \end{array}$

Samojloff, A. J. $\ldots . \quad \ldots . \quad \ldots \quad 653$

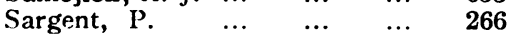

Schall, E. ... $\quad \ldots \quad \ldots . \quad \ldots \quad 416$

$\begin{array}{llllll}\text { Schindler } & \ldots & \ldots & \ldots & \ldots & 543\end{array}$

Schiötz, H. A. (Öbituary) $\ldots . \quad 171$

$\begin{array}{lllll}\text { Schlodtmann } & \ldots & \ldots & \ldots & 615\end{array}$

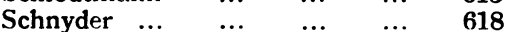

Schoenberg, M. ... . ... 594, 597

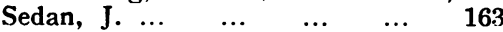

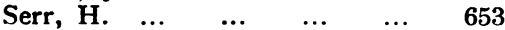

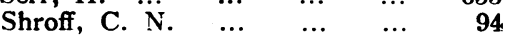

Simon, $\begin{array}{lllll}\text { S. } \ldots & \ldots & \ldots & \ldots & 94 \\ & & & & \end{array}$ 


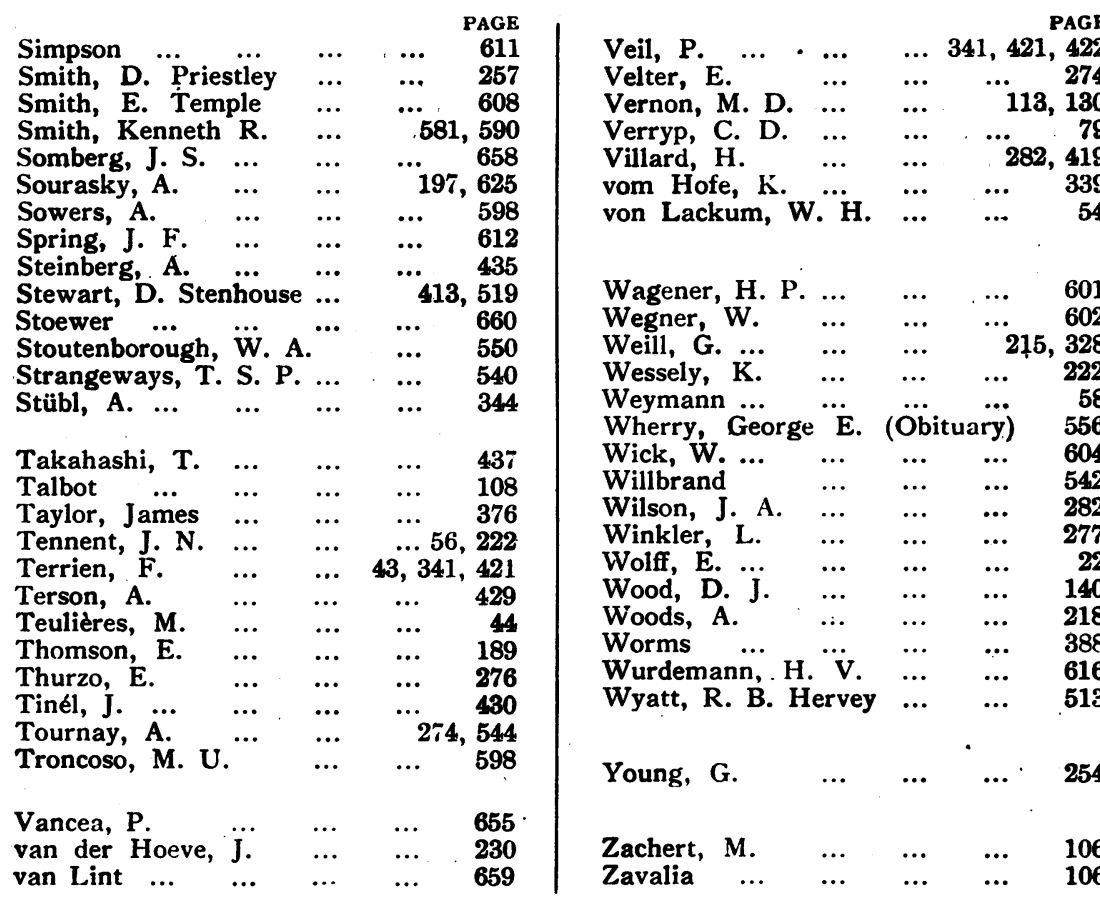




\section{SUBJECTS.}

Entries printed in thick type indicate grouped or special abstracts.

Accommodation and convergence in normal and in pat holog i cal states, ocular tension during ...

paralysis of- of several years' duration, in patients affected by epidemic encephalitis, and on a postencephalitic Parinaud's syndrome...

Accommodative balance test, an

Addison's disease, ocular findings

Adenoma of conjunctiva containing Meibomian glands ...

Ametropia, conditions of, quadruple stenopaic hole and

Anaesthetic injections, retroorbital, aseptic toxic cellulitis following ...

Aneurysm of anterior cerebral artery causing compression of optic nerves and chiasma ...

Angiopathia retinae traumatica (Purtscher), with remarks on pigment-migration ...

Anisocoria, normal, in extreme lateral fixation ... ... 544

Annotations $\ldots \quad 35,95,147,212$, $261,322,379,415,590,648$

Annular scotoma ... $\quad \ldots \quad \ldots \quad 345$

Anterior chamber, conjunctival drain of ...

cornea and Descemet's membrane, early development of endothelium of

Appointments $63,112.174,237,286$, $397,444,509,556$

Aqueous, hydrogen-ion concentration of ...

Argentine, trachoma in, prophylaxis of ... ... ...

Arsenobenzol, transitory spasmodic myopia due to

Arterial pressure, retinal ...

in syphilitics, Influence of lumbar puncture on $\ldots$..

spasm in production of occlusion of branches of central artery of retina...

Arthritis, chronic, keratitis filamentosa and .
Bacon, Roger, c. 1214-1294 (The Father of British Optics)

Bacteriology of hypopyon ulcer

Baryta, burns of eye by, prognosis of ... ... ...

Binocular vision, modifications of sensation of relief (or prominence) produced by decentred spectacle lenses and by prisms in...

Binoscope ...

Birth trauma to cornea $\ldots . \quad \ldots .661$

Blind in Scotland, care of $\quad \ldots .379$

Blind man, provision for, an early example of $\quad \ldots \quad 397$

Blindness, functional, case of ... 666 medical certificates of, for persons applying at voluntary hospitals ... sudden, from serous meningitis $\quad \ldots \quad \ldots \quad \ldots$

Blood calcium of children, $\ddot{0} \ddot{b}-$ servations on ... ...

corpuscles and retinal circulation, entoptic examination of, simple apparatus for ... ... ... ... pressure in "intra - ocular vessels $\ldots \quad \ldots \quad \ldots$

in ocular vessels, measurement of, by pressure-pad method ... ... $\ldots 653$

Bone formation in lens, seven $\begin{array}{lllll}\text { cases of } & \ldots & \ldots & \ldots & 220\end{array}$

Bowman Library ... $\quad \ldots . \quad \ldots . \quad 147$

British Medical Association, Annual Meeting, section of ophthalmology 347, 500

British Optics, the Father of (Roger Bacon, c. 12141294) hemical, of eve, prognosis of $\ldots \quad \ldots \quad \ldots \quad \ldots$

of eye, transplantation of mucous membrane of mouth in ... ... ... 661

Cancer, intraocular, unrecognized, preventive radium therapy of or bit $\ldots$ salt, $\ldots$

Cargentos, a new silver salt, in
ocular therapeutics $\ldots$ 
Cataract and its connection with general pathology $\quad \ldots \quad 215$

congenital $\quad \ldots \quad \ldots \quad \ldots 618$ experimental production of, and its inheritance in fowls ... ... ... operation on, remote results $\begin{array}{lllll}\text { of } & . . & \ldots & \ldots & 221\end{array}$

extraction, after-results of ... 85 conjunctival bridge in ... 525 intracapsular, wound-fixation for with peripheral iridectomy

non-operative treatment of, with report on lens antigen treatment

of myotonia, degenerative corneal changes in, case of $\ldots \quad \ldots \quad \ldots$.... operations, infection in, prevention of

palpebral suture after, with or without a dressing...

preliminary iridectomy in, great value of... ...

secondary, operations for, technique of $\ldots . \quad \ldots$ subcapsular, familial, presenile, hitherto unknown type of, with simultaneous familial changes in vitreous $\quad . . . \quad \ldots$...

Cataractous and non-cataractous individuals, sera of ...

Cellulitis, toxic, aseptic, following retro-orbital anaesthetic in jections

Cerebral artery, anterior, aneurysm of, causing compression of optic nerves and chiasma ...

Chaulmoogra oil in treatment of trachoma... ... ...

Chemical burns of eye, prognosis of ... $\ldots$... $\ldots$

Chiasma, nerve fibres in, course

Children, blood calcium of, observations on $\quad \ldots \quad$... 419

trachoma in ... $\quad \ldots \quad \ldots \quad 106$

unilateral chronic anterior uveitis in ... $\quad . . \quad \ldots \quad 189$

Chimpanzeeand macacus rhesus, chronic granular conjunctivitis in, induced by inoculation of culture of micro-organism isolated from cases of American Indian trachoma
Cholesterin, changes produced by, on ocular vessels of animals and importance of iodine as preventive .

Choroid, melanotic sarcoma of, presenting histologically endotheliomatous characters $\ldots$... $\ldots$ spontaneous separation of choroid simulating $\quad \ldots \quad$... tumour of, early symptoms of

Choroid a l atrophy, juxtapapillary, frequency of senile non-myopic crescent conus in connection with $\quad \ldots \quad \ldots$...

Choroiditis, retinosis and retinosis externa

Chorio-retinal oedema, iodine in 246

Circinate degeneration, histopathology of, case of ... 599

Cocaine, Carl Koller and ...

Cold, prolonged application of, to eye, case illustrating effects of ... ... ...

Colour abnormalities, congenital, an indelible "3-object", comparative test for ...

fields, size and shape of, effect of size of stimulus on ... $\quad \ldots \quad \ldots$

scotoma, central, an indelible "3-object" comparative test for ... ... ...

Concomitant strabismus and heterophoria $\quad . . \quad \ldots 581$

Congress, Ophthalmological, International, $1929 \quad 37,155$

Conjunctiva, adenoma of, containing Meibomianglands and cornea, xerosis of, pathology of $\quad \ldots \quad \ldots \quad \ldots$ serious haemorrhage from, in infant, following instillation of silver nitrate solu$\begin{array}{lllll}\text { tion } \quad \ldots & \ldots & \ldots & 33\end{array}$

spring catarrh of $\quad \ldots \quad \ldots 385$

syphilitic chancre of, in boy aged 7 years $\quad \ldots . \quad \ldots .654$

water-tight closure of, iridencleisis with $\quad . . \quad$...

Conjunctival bridge in cataract extraction $\quad \ldots \quad \ldots$

circulation, study of ; subconjunctival migration of Chinese ink during five $\begin{array}{lllll}\text { years } \quad \ldots & \ldots & \ldots & 386\end{array}$

drain of anterior chamber ... 391

Conjunctivitis, chronic, nasal infection and $\quad \ldots \quad \ldots 383$ 
Corjunctivitis, gonococcal, metastatic, efficiency of protein therapy in ...

granular, chronic, induced in macacus rhesus and chimpanzee by inoculation of cultures of microorganism isolated from cases of American Indian trachoma... $\quad . . \quad \ldots \quad 387$

Parinaud's, two cases of $\quad \ldots \quad 79$ with suppuration in preauricular submaxillary and supraclavicular glands $\ldots \quad \ldots \quad \ldots \quad 383$ $\begin{array}{llllll}\text { vernalis } & \ldots & \ldots & \ldots & 385\end{array}$

Conjunctivo-plasty in certain corneal affections ...

Convergence and accommodation in normal and in pathological states, ocular tension during

Copper, in travenous injection of in trachoma $\quad . . \quad \ldots \quad 104$

Cordoba, district of, trachoma in 106

Cornea and conjunctiva, xerosis of, pathology of... ...

anterior chamber, and Descemet's membrane, early development of endothelium of $\quad . . \quad$...

birth trauma to $\quad \ldots \quad \ldots 661$

cysts of, bilateral $\quad . . \quad \ldots \quad 249$

erosion and ulceration of, heat in treatment of ...

formation of vesicles and cysts on surface and in substance of

fusiform pigmentation of $\quad \ldots \quad 436$

gold and silver impregnation of, for cosmetic purposes

radiation of, with ultra-violet light, especially in ulcus serpens $\ldots \quad \ldots \quad \ldots$ tattooing of, by chemical method with silver nitrate, gold chloride and platinum chloride

ulcer of, due to bacillus of Petit, case of ... ulceration of .. $\quad$... $\quad$... various diseases of, transplantation of mucous membrane from mouth in

Corneal affections, conjunctivoplasty in ... ... $\ldots$ changes, degenerative, in cataract of myotonia, $\begin{array}{lllll}\text { case of } \ldots & \ldots & \ldots & 48\end{array}$

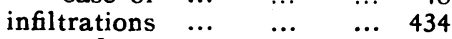
Correspondence $\ldots \quad \dddot{168}, 110,236$, $285,555,666$
Coward, William, 1658-1725 _.. 241

Cyclodialysis upon eyes of rabbits $\quad \ldots \quad \ldots \quad \ldots$

Cysts and vesicles on surface and in substance of cornea, formation of $\quad . . \quad \ldots .660$ $\begin{array}{llll}\text { of cornea, bilaterai } & \ldots & \ldots & 249\end{array}$

Dacryocystitis, chronic, treatment of $\ldots \quad \ldots \quad \ldots . \quad \ldots \quad 416$ by paraftin injection ... 419

Dacryops: subconjunctival $\ldots 418$

Depigmentation in irides of an adult... $\quad \ldots \quad \ldots \quad \ldots$ Descemet's membrane, the cornea, and anterior chamber of eye, early development of endothelium of $\quad \ldots \quad$... $\quad \ldots \quad 479$

Deviated eye, strabo-tenotomy of 334

Diathermy in ophthalmology ... 605

in treatment of trachoma $\ldots \quad 388$

Diathesis, or the influence of soil in the causation and treatment of disease ... ...

Diplopia, functional, in a schoolboy $\quad \ldots$... $\quad$. .

Disease, early symptoms of, with special reference to the eye $\quad \ldots \quad \ldots . \quad \ldots \quad 425$

Divergence excess, its diagnosis and treatment $\ldots \quad \ldots 330$

Dry sterilization for eye instruments $\quad \ldots \quad \ldots \quad \ldots \quad 505$

Echinococcus cyst of orbit in a Chinese ... ... ...

$\begin{array}{llll}\text { Ectropium uveae, acquired } \quad \ldots & 612\end{array}$ 435. Embolism of branch of central artery of retina after injection of metarsenobenzol $\quad \ldots \quad \ldots$...

Embryonic tissues growing in vivo and in vitro, differentiation of, experimental studies on

Empyema, sphenoidal, bilaterai. case with mainly ocular manifestations ... ...

Encephalitis lethargica, ocular crises of $\ldots \quad \ldots \quad \ldots$

Endophytic retinal glioma $\dddot{\text { in }}$ $\begin{array}{lllll}\text { adult } \quad \ldots & \ldots & \ldots & 597\end{array}$

Endothelioma, haemangiomatous,

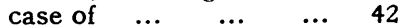
$\begin{array}{lllll}\text { suprasellar } & \ldots & \ldots & \ldots & 42 \\ & \ldots & \ldots & 266\end{array}$

Endothelium of Descemet's membrane, the cornea and the anterior chamber of eye, early development of ... 
Entoptic examination of retinal circulation and of blood corpuscles, simple apparatus for $\quad . . \quad$...

Entropion of upperlid, Webster's operation for ... ...

Entropium uveae ... . ... ...

Enucleation, ivory implant after
Epidemic encephalitis, paralysis of accommodation of several years' duration in patients affected by ...

Episcleritis and tuberculin treatment $\quad \ldots \quad \ldots \quad \ldots$

Ergotamine in treatment of glaucoma $\ddot{\text { and }}$ ulceration of cornea,

Erosion and ulceration of cornea,

Exophthalmic goitre, extreme cases of, section of levator palpebrae in ... ...

Exophthalmos, intermittent, of nasal origin ... $\ldots$...

Eye and adnexa, diseases of, radium therapy in

burns of, transplantation of mucous membrane of mouth in ... ... ...

chemical burns of, prognosis of $\ldots \quad \ldots \quad \ldots \quad \ldots$

effects of prolonged application of cold to, case illustrating $\quad . . \quad$...

growth of, and the development of myopia: study in changes of refraction during school period ...

inflammatory diseases of, pelvic organs as foci of infection in $\quad . . . \quad \ldots$.

in insanity $\quad \ldots \ldots$... $\ldots$ ment reaction in

instruments, dry sterilization for... ... ... ...

movements, method of $\ddot{\text { re- }}$ cording ... ... ...

plastic surgery of, $\ddot{m u c o u s}$ membrane from middle turbinate in ... ...

the, and spectacles, in heraildry $\quad \ldots \quad \ldots \quad \ldots$

Eyes, movements of the, $\ddot{\text { in read- }}$ ing... $\ldots$... $\ldots$...

Eyeball, conditions of arising
from retro-pharyngeal disease ... ... ... pressure on, folds in retina caused by $\quad$... ... surface of, rod palpatory method for examination $\begin{array}{llll}\text { of } \quad . . & \ldots & \ldots\end{array}$
PAGE
Foetal ocular inflammation $\ldots .34$

Foreign body, intra - ocular, aseptic serous meningitis following ... ... ... diagnosis of, co-operation of direct observation with use of magnet in ... very small, diagnosis of, use of galvanometer in $\quad \ldots .284$

French Cameroons, trachoma in 108

Frontal sinus, of spacious type. collapse of $\ldots$...

Fundus changes in hypertension with and without nephritis $\quad \ldots \quad \ldots . \quad \ldots \quad 424$

the ocular, in the acute toxae$\begin{array}{lllll}\operatorname{mias} \quad \ldots & \ldots & \ldots & 427\end{array}$

Fusion impulse, suspension of, as therapeutic measure 329

Future arrangements $64,112,176$ $237,287,347,398,557,621,670$

Galvanometer, use of, in diagnosis of very small intra-ocular foreign bodies $\ldots$... ...

General Medical Council, work

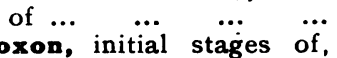

Gerontoxon, initial stages of, development of ... $\quad \ldots \quad 662$

Gifford Edmonds Prize... ... 176

Glands, preauricular, submaxillary and supraclavicular. suppuration in, Parinaud's conjunctivitis with ...

Glaucoma, acute attacks of, prevention of, by glaucosan 548

$\begin{array}{lllll}\text { chronic } & \ldots & \ldots & \ldots & 390\end{array}$

congenital, of unusual type... 248

in generalized vascular naevus of skin $\ldots \quad \ldots \quad \ldots \quad 546$

medical treatment in, clinical and experimental contributions concerning $\quad \ldots \quad 546$

$\begin{array}{llll}\text { peculiar case of } \quad \ldots & \ldots & 74\end{array}$

relation of nasal ganglion to 391

sclero - post - iridectomy, a rational operation in ... 393

treatment of, ergotamine in... 548

Glaucosan, prevention of acute attacks of glaucoma by...

Glial system of intra-cranial optic nerves, anatomy and physiology of $\quad . . \quad \quad \ldots \quad 543$

Glioma of retina and its treatment by X-rays... $\quad \ldots \quad \ldots \quad 41$

bilateral, case of, cured in non-enucleated eye by radium treatment $\quad$... 597

endophytic, in adult... $\quad . .597$

two cases observed in later childhood and in an adult 
PAGE

Globe, anterior segment of, bone-free Röntgen photography of

See also Eyeball

Gonococcal conjunctivitis, metastatic, efficiency of protein therapy in

Haemorrhage, retinal, massive serious, from conjunctiva in infant, following instillation of silver nitrate solution

Haemangiomatous endothelioma, a case of ... ...

Heat in treatment of erosion and ulceration of cornea ...

Heraldry, eye and spectacles in Hess's operation for ptosis in case of myasthenia gravis ...

Heterophoria, apparatus for exercising $\quad \ldots \quad \ldots \quad 590$ concomitant strabismus and 581

Honours $\quad . . \quad \ldots \quad \ldots 6 \quad 63,510$

Hospital, large, social work of... 415

Hospitals, voluntary, pay-beds in $\mathbf{5 3 0}$

Hydrogen ion concentration of aqueous ... ... ...

Hypertension with and without nephritis, fundus changes in $\ldots$... $\ldots$...

Hypopyon keratitis, aetiology and treatment of $\ldots$... ulcer, aetiology and treatof $\ldots \quad \ldots \quad 431,432,522$ bacteriology of $\quad . . \quad 431,432$ operative treatment of $\ldots 433$ treatment of $\quad \ldots \quad \ldots 667$

Hypotonus, ocular, its causes, dangers and treatment...

Illuminating Engineer, The $\ldots \quad 212$

Engineering Society ... ... 510

Impregnation of cornea, with gold and silver, for cosmetic purposes ... ...

Indians of the South-west, trachoma among $\quad . . \quad \ldots \quad 102$

Insanity, the eye in $\quad . . \quad \ldots \quad 56$

Instruments, sharp, sterilization of ...

Insulin, action of, $\ddot{\text { on pancreatic }}$ diabetic dog, ophthalmological studies on ...

Insured workmen, loss of orientation in $\ldots$... ...

International Ophthalmological Congress, 1929, 37, 155, 347, 380

Intracapsular extraction of cataract, wound-fixation for
Intracisternal in jections in luetic optic atrophy, results with $\quad . .6 \quad \ldots . \quad \ldots \quad 659$

Intracranial complications of orbito-ethmoidal osteomata $\quad . . \quad \ldots \quad \ldots$ optic nerves, glial system of, anatomy and physiology of ... $\quad \ldots$... ...

Intraocular cancer, unrecognized. Preventive radium therapy of orbit... ...

foreign body, aseptic serous meningitis following ...

diagnosis of, co-operation of direct observation with use of magnet in $\quad .$. very small, diagnosis of, use of galvanometer in... pressure, influence of a compression bandage on ... 550 tumours, latent, juxta-papillary leuco-sarcoma with irido-cyclitis $\quad . . \quad \ldots .643$

unrecognized $\quad \ldots . \quad \ldots \quad 595$

vessels, blood-pressure in... 653

Intravenous injections of cyanide of mercury, value of $\ldots 660$

lodine in chorio-retinal oedema 246

Ionisation, zinc, in ophthalmic work $\quad \ldots \quad \ldots \quad \ldots$

Iridectomy, peripheral, $\ddot{\text { cataract }}$ extraction with ... 223, 224

preliminary, in cataract opertion, great value of

Iridencleisis, with meridional iridotomy in acute glaucoma $\quad . . \quad \ldots$...

with water-tight closure of conjunctiva $\quad . . . \quad \ldots$

Irides of an adult, depigmentation of $\ldots \quad \ldots \quad$... $\quad \ldots \quad 615$

Irido-cyclitis, juxta-papillary leuco-sarcoma with ...

Iridotomy, meridional, iridencleisis with, in acute glaucoma $\quad \ldots \quad \ldots \quad$... 549

Iris, essential atrophy of... $\quad \ldots .613$

melanosis of, and new formation of hyaline membrane on its surface

old inflammatory, incarcerations and prolapses of. isolation of $\quad \ldots \quad \ldots$

lechaemia of retina, rare ophthalmoscopic appearance in ... $\quad . . \quad$... $\quad .$. experimental, function of human retina under 
Keratitis, filamentosa and chronic arthritis ... $\ldots, \quad \ldots$

hereditary and familial, examined with ophthalmic microscope, case of ...

hypopyon, aetiology and

treatment of $\ldots .$.
interstitial, syphilitic, posttraumatic. Rôle of subconjunctival haemorr-

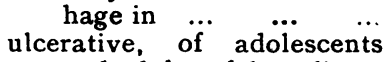
and adults of hereditary syphilitic origin . ...

Kerato-malacia, pathology of ... Koller (Carl), and cocaine

Lacrymal passages, visualization of, by use of lipiodol ...

Lamp for ophthalmic work ...
Lebanon and Syria, trachoma in. frequency, clinical forms aetiological factors and geographical distribution of $\ldots \quad \ldots \quad \ldots \quad 389$

Leechdoms, ophthalmic... $\quad \ldots .401$

Lens, bone formation in, seven cases of $\ldots . . .6$ non-

antigen treatment in nonoperative treatment of cataract ... … $\because$.

crystalline, congenital opaci-
ties of anterior polar region of, and their correlation with malformations of pupillary membrane

protein and its fractions $\ldots .218$

transparent, in high myopia, extraction of ... ...

Leuco-sarcoma, juxta-papillary, irido-cyclitis with ...

Levator palpebrae, section of; in extreme cases of exophthalmic goitre $\quad$..

Lid, upper, entropion of, Webster's operation for

Light bath treatment, general, in diseases of the eye ... ultra-violet, in treatment of ophthalmological conditions $\ldots$... $\ldots$

Limbus, melanotic sarcoma of,
secondary generalised
sarcomatosis of skin ...
Lipiodol, visualization of lacry-

Limbus, melanotic sarcoma of,
secondary generalised
sarcomatosis of skin ...
Lipiodol, visualization of lacrymal passages by use of ...

Literature, ophthalmic, contemporary $238,287,348,398,445$. $510,558,622,670$

Loupe, operating, new $\ldots \quad \ldots \quad 257$
Luetic optic atrophy, results with intracisternal injections in $\ldots$ optic nerve pallor with-

Luetice, optic nerve pallor with-
out functional distur-
bance in ... $\ldots$

Luetice, optic nerve pallor with-
out functional distur-
bance in ... $\ldots$ retinal arterial pressure $\begin{array}{llll}\text { in syphilitics } & \ldots & \ldots & 656\end{array}$

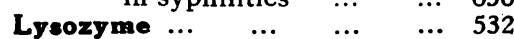

Macacus rhesus and chimpanzee, chronic granular conjunctivitis in, induced by inoculation of cultures of micro-organism isolated from cases of American Indian trachoma ...

Mackenzie (William) Memorial Medal, first award of 397, 648

Macular degeneration, unusual case of $\quad \ldots \quad \ldots \quad \ldots$

Magnet, use of, in diagnosis of intra-ocular foreign bodies, co-operation of direct observation with

Medical certificates of blindness for persons applying at voluntary hospitals $\ldots$

Meibomian glands contained in

337 adenoma of conjunctiva tion of hyaline membrane on its surface ... ...

Melanotic sarcoma of choroid presenting histologically endotheliomatous characters ... ... $\ldots$ lowing intra-ocular foreign body $\quad \ldots \quad$... 644 sudden blindness from $\quad \ldots .426$

Mercury, cyanide of, intravenous in jections of, neuritis of optic nerve, fifth nerve and of third nerve cured

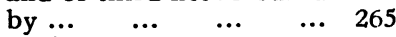
$\begin{array}{lllll}\text { value of } & \ldots & \ldots & \ldots & 265 \\ & \ldots & \ldots & \ldots & 606\end{array}$

Meta-sy philis of eye $\ldots . .$.
Microscope, oph thalmic, case of hereditary and familial keratitis examined with

Micrometric ophthalmoscope $\begin{array}{lllll}\text { lens } & \ldots & \ldots & \ldots & 162\end{array}$

Middle ear, pupil and ... $\ldots .339$

Monocular occlusion, prolonged, diagnosis of latent vertical deviations of eyes by use of $\ldots \quad \ldots \quad \ldots \quad 331$

Monograph supplements and books $\quad \ldots \quad \ldots \quad \ldots \quad 36$ 
Motion pictures, effect of viewing on visual acuity...

PACE

Mouth, mucous membrane from transplantation of, in various diseases of cornea and burns of eye...

Movements of the eyes in reading

Mumps, ocular complications of

Myasthenia gravis operated on for ptosis by Hess's method, case of ... ...

Mydriasis, unilateral, case of .... Myelitis, diffuse, associated with optic neuritis

Myopia and school work _.. 648

development of, growth of eye and : study of changes of refraction during school period

development of, race, sex and environment in ... ...

high, extraction of transparent lens in ... $\quad \ldots \quad 220$

inflammatory ... $\quad \ldots \quad \ldots \quad 163$

spasmodic, transitory, due to arsenobenzol $\quad \ldots \quad \ldots$

Myotonia, cataract of, degenerative corneal changes in, case of

Naevi, vascular, radium in treatment of ... $\quad . . \quad \ldots$

Nae vus, general vascular, of skin, glaucoma in ... ... 546

Nasal ganglion, relation of, to glaucoma... $\quad \ldots \quad \ldots$

infection, chronic conjunctivitis and $\quad . . \quad \ldots$ origin, intermittent exophthalmos of ... ...

Naso-lacry mal duct, stenosis of, pathological anatomy ...

Nerve fibres in chiasma, course of

Neuritis of optic nerve, of fifth nerve, and of third nerve, cured by intra-venous injections of cyanide of mercury ... ... ...

Neuroblastoma, metastatic, of orbit, case of ... ...

Neurofibromatosis of right orbit. case of ... ... ...

Neuro-gliomatosis palpebroorbital ... $\quad . . \quad \ldots 4421$

Neurological and ophthalmological interest, cases of

triad, a great ... $\ldots$...
North of England Ophthalmological Society, Officers 286

Notes $\ldots 63,111,174,237,286,346$. $397,444,509,556,669$
Nuclear ophthalmoplegia, with

PAGE special reference to retraction of lids and ptosis, and to lesions of posterior commissure $\quad . . \quad \ldots$

Nystagmus, hereditary, genesis of $\ldots \quad \ldots \quad \ldots \quad \ldots \quad 50$

Obituary

$62,111,169,346,396$, $444,556,669$

Occlusion test, prolonged, observations on $\quad \ldots \quad \ldots . \quad 331$

Ocular complications of mumps 419 crises of encephalitis lethar$\begin{array}{lllll}\text { gica } & \ldots & \ldots & \ldots & 430\end{array}$ diseases, protein shock therapy in, problems of $\quad . .604$

findings in Addison's disease 423 hypotonus, its causes, dangers and treatment $\quad \ldots \quad \ldots \quad \ldots 338$

inflammation, foetal... ... 344 muscle imbalance, latent, significance of $\quad . . \quad \quad \ldots \quad 329$

tension during accommodation and convergence in normal and in pathological states $\quad . . \quad \ldots \quad 544$ therapeutics, cargentos, a new silver salt, in $\quad \ldots \quad 607$ vessels of animals, changes produced by cholesterin on, and importance of iodine as preventive $\quad . .284$

Ophthalmic benefit and clinics... 213 leechdoms $\quad \ldots \quad$... $\quad \ldots \quad 401$ literature, contemporary ... 238, $287,348,398,445,510,558,622,670$ miracles $\quad \ldots \quad \ldots . \quad \ldots \quad 95$ work, lamp for $\quad \ldots . \quad \ldots . \quad 321$ Ophthalmitis, sympathetic 254,280 . 281,283

produced by herpes virus (v. Szily) experiments on

Ophthalmological and neurological interest, cases of conditions, ultra-violet light in treatment of ...

Congress, International, 1929 $37,155,347,380$

Society of the United Kingdom, Annual Congress of studies on pancreatic diabetic dog, with remarks on action of insulin...

Ophthalmologiste, B $\mathbf{r}$ it i $\mathbf{h}$, C o u n c il of, Annual Report ... $\ldots$...

medical certificates of blindness for persons applying at voluntary hospitals 
Ophthalmologists, Brit ish, Council of, report on inquiry as to how far the recommendations of the departmental committee on causes and prevention of blindness with reference to ophthalmia neonatorum have been put into practice

Ophthalmology, diathermy in... Ophthalmoplegia, nuclear, with special reference to retraction of lids and ptosis, and to lesions of posterior commissure $\quad . . \quad \ldots$

Ophthalmoscope lens, micrometric $\ldots$... ...

retinoscope and hand slitlamp combined ... ...

Optic atrophy, due to compression of optic chiasma by new growth $\quad . . \quad$.. sulphur treatment of $\quad \ldots$ tabetic, therapeutic measures in $\ldots$...

canals, one thousand, report on $\ldots \quad \ldots \quad \ldots \quad \ldots$

chiasma, compression of, by new growths, optic atrophy due to ... ... nerve, fifth nerve, third nerve, neuritis of, cured by intra-venous injections of cyanide of mercury ...

nerve pallor without functional disturbance in luetics $\quad \ldots . \quad \ldots \quad \ldots$ nerves and chiasma, compression of, caused by aneurysm of anterior cerebral artery ...

intra-cranial, glial system of, anatomy and physiology of $\ldots \quad$...

neuritis, diffuse, myelitis associated with ... ...

$\begin{array}{llll}\text { significance of } & \ldots & \ldots & 276\end{array}$

$\begin{array}{llllll}\text { unilateral } & \ldots & \ldots & \ldots & 277\end{array}$

$\begin{array}{lllll}\text { Opticians Bill } & \ldots & \ldots & \ldots & 63\end{array}$

registration of, report of committee on $111,147,155$

Optico-ciliary, veins on papilla 320

Orbit, apex of, paralytic syndromes of

contents of, rod palpatory method for exploration of $\ldots$... $\quad \cdots \quad \ldots$ echinococcus cyst of, in a Chinese ... ... ... metastatic neuroblastoma of, case of
PAGE

Orbit, of new-born child, true filial teratoma and cyst in preventive radium therapy of, in unrecognised intraocular cancer ... ... right, neurofibromatosis of, case of $\quad . . \quad \ldots \quad \ldots$

Orbital cavity, extraction of thorn from

Orbito - ethmoidal osteomata having intracranial complications, experiences with $\quad \ldots \quad$... $\quad .$.

Orbito-palpebral cancers, radiotherapy of, technique of Paris Radium Institute tion in insured workmen loss of $\ldots \ldots \quad \ldots$.

Osteomata, orbito - ethmoidal, having intracranial complications, experiences with $\quad \cdots \quad \ldots, \quad \cdots$

Oxford Ophthalmological Congress, XVIII Annual Congress ... ... 237, 496

Palpebral suture, with or without a dressing, after cataract operations ...

Palpebro-orbital neuro-gliomatosis $\quad \ldots \quad \ldots \quad \ldots$

Pancreatic diabetic dog, oph thalmological studies on, with remarks on action of insulin $\quad \ldots$... ...

Papilla, optico-ciliary veins on...

Paraffin injection in treatment of chronic dacryocystitis

Paralytic syndromes of apex of orbit $\quad \ldots \quad \ldots \quad \ldots .264$

Parinaud's conjunctivitis, two cases of $\ldots \quad \ldots \quad \quad \ldots$

with suppuration in preauricular, submaxillary and supraclavicular glands... syndrome,post-encephalitic

Paris Radium Institute, technique of, in radiotherapy of orbito-palpebral cancers

Pay-beds in voluntary hospitals

Pelvic organs as foci of infection in inflammatory diseases of eye $\quad \ldots \quad \ldots . \quad \ldots \quad 54$

Perimetry, quantitative ... $\quad \ldots \quad 34$

Petit, bacillus of, ulcer of cornea due to ... ... ... 434

Phototherapy in ophthalmology 227,353

Pigment complement reaction in in iuries of eye ... $\quad . .615$ migration, angiopathia retinae traumatica (Purtscher) and... 570 
xvii.

PAGE

Polish Oph thalmological Clinic..

Pregnancy, fields of vision in last weeks of, examination of

Pressure-pad method in measurement of bloodpressure in ocular vessels

Protein therapy, efficiency of, in metastatic gonococcal conjunctivitis ... ... in ocular diseases, problems of $\ldots \quad \ldots \quad$... $\quad .$.

Proteins, lens, and its fractions Psendoglaucoma... ... ...

Pterygium, therapy of ... ...
Ptosis in myasthenia gravis, opertion by Hess's method, case of $\quad \ldots \quad \ldots \quad$...

Pupil and middle ear $\quad \ldots \quad$... 339

Pupillary inequality $\quad \ldots \quad \ldots \quad 274$

membrane, malformations of, correlation of congenital opacities of anterior polar region of crystalline lens with $\quad \ldots \quad \ldots \quad \ldots$

Purtscher, angiopathia retinae traumatica of : with remarks on pigment migration $\quad \ldots \quad \ldots \quad \ldots$

Quadruple stenopaic hole and conditions of ametropia

Race, sex and environment in development of myopia ...

Radiating the cornea with ultraviolet light, especially in ulcus serpens ... ...

Radiotherapy of orbito-palpebral cancers, technique of Paris Radium Institute

Radium, treatment of vascular naevi $\quad \ldots \quad \ldots \quad$...

in disease of eye and adnexa preventive, of orbit in unrecognised intraocular cancer $\quad \ldots \quad$...

successful, of non-enucleated eye in bilateral glioma of retina $\ldots \ldots$

Reading, movements of the eyes in ... $\ldots$ disease $\ldots$

Recklinghausen's disease, incomplete forms of ...

Recording of eye movements. method of ... ...

Refraction, changes in ${ }_{i}$ during school period: growth of eye and development of myopia $\quad$... ... double, case of $\quad \ldots . \quad \ldots 664$
Registration of opticians, report of committee on $111,147,155$

Research work in ophthalmology 214

Retina, bilateral glioma of, case of, cured in non-enucleated eye by radium treatment $\ldots$... ...

central artery of, embolism of, after injection of metarsenobenzol

central artery of, occlusion of branches of, arterial spasm in production of...

endophytic glioma of, in adult

folds in, caused by pressure on eyeball

597

glioma of, and its treatment by $\mathrm{X}$-rays... $\quad \ldots \quad \ldots$ human, function of, under experimental ischaemia retinae $\ldots \quad \ldots \quad \ldots$

ischaemia of, experimental. function of human retina $\begin{array}{llllll}\text { under } & \ldots & \ldots & \ldots & 602\end{array}$

rare ophthalmoscopic appearances in ... $\quad \ldots 601$

Retinal arterial pressures $\quad \ldots .650$

in syphilitics, influence of lumbar puncture on ... circulation and blood corpuscles, entoptic examination of, simple apparatus for...

haemorrhage, massive $\quad \ldots \quad 313$

layers in vertebrates, process of differentiation of $\quad .$.

Retinitis circinata, histo-pathology of, case of ... $\quad$.. 599

$\begin{array}{llll}\text { punctata albescens ... } & \ldots & 598\end{array}$

Retinoblastoma and recent views on malignancy ...

610 Retinoscope, hand slit-lamp and ophthalmoscope, com-

$\begin{array}{lll}611 & \text { bined } \ldots & \ldots\end{array}$ choroiditis ... ...

Retro-orbital anaesthetic injections, aseptic toxic cellulitis following ... ... ditions of eyeball arising from $\quad \ldots \quad \ldots$...

130 Rheumatic diseases, conference $\begin{array}{llllll}\text { on } \ldots & \ldots & \ldots & \ldots & 112\end{array}$

Rhinosporidium Kinealyi, case of

Rod palpatory method for exploration of orbital contents and surface of eyeball

Röntgen photography, bone-free, of anterior segment of globe 
Royal London Ophthalmic Hospital Annual Dinner 111, 174

Royal Westminster Ophthalmic Hospital, rebuilding of

Sarcoma, melanotic, of limbus : secondary generalised sarcomatosis of skin ...

of choroid, melanotic, presenting histologically endotheliomatous characters

Sarcomatosis of skin, generalised, secondary to melanotic sarcoma of limbus

School period, changes of refraction during: growth of eye and development of myopia $\quad$... $\quad .$.

work, myopia and $\ldots \quad \ldots$

Scloro-post - iridectomy, a rational operation in glaucoma... ... ...

Scotland, care of blind in ...

Scotograph : instrument to facilitate fields of vision in central scotoma ...

Scotoma, annular... ... ... central, instrument to facilitate fields of vision in : the scotograph ... ...

Senile non-myopic crescent conus in connection with juxtapapillary choroidal atrophy, frequency of ...

Sera of cataractous and noncataractous individuals

Serotherapy in trachoma ...

$\begin{array}{lllll}\text { Siderosis } & \ldots & \ldots & \ldots & \ldots\end{array}$

Silver nitrate solution, instillation of, serious haemorrhage from conjunctiva of infant following ... ...

Sixth cranial nerve, a bend in, and its probable significance

Skin, generalised vascular naevus of, glaucoma and ... secondary generalised sarcomatosis of, in melanotic sarcoma of limbus

Slit-lamp, hand, ophthalmoscope and retinoscope, combined $\quad \ldots \quad \ldots$...

Slovakia, trachoma in, the fight against $\ldots$... $\ldots$

Smith's apparatus for exercising heterophoria (binoscope)

Social work of a large hospital
Spectacle lenses, decentred, and prisms, in binocular vision, modifications of sensation of relief (or prominence) produced by

Sphenoidal empyema, bilateral, case with mainly ocular manifestations ... $\quad \ldots \quad 413$

$\begin{array}{llll}\text { Spring catarrh of conjunctiva } & \ldots & 385\end{array}$

Squint, children's, and heterophoria $\quad . . \quad \ldots \quad \ldots \quad \ldots \quad 581$

operation, mechanics of $\quad \ldots \quad 333$

Sterilization, dry, for eye instruments $\quad \ldots \quad \ldots \quad 505$ $\begin{array}{llll}\text { of sharp instruments } & \ldots & 594\end{array}$

Strabismus, concomitant and heterophoria $\quad . . \quad$... 581

$\begin{array}{llllll}\text { causes of } & \ldots & \ldots & \ldots & 332\end{array}$

Strabo-tenotomy of deviated eye 334

Subconjunctival dacryops $\quad \ldots \quad 418$ haemorrhage, rôle of, in posttraumatic syphilitic interstitial keratitis ... $\quad \ldots \quad 658$ migration of Chinese ink during 5 years ... $\ldots .386$

Subjunctive eye (the third eye) 229 Sulphur treatment of optic $\begin{array}{lllll}\text { atrophy } & \ldots & \ldots & \ldots & 277\end{array}$

Suprasellar endotheliomata $\ldots .266$

Sympathetic ophthalmitis 254.280

produced by herpes virus 281,282 (v. Szily), experiments on $\quad . . \quad \ldots$... 279

Syphilitic chancre of conjunctiva in boy aged 7 years tarsitis of polypoid type ...

Syphilitics, retinal arterial pressure in, influence of lumbar puncture on ...

Syria and Lebanon, trachoma in, frequency, clinical forms. aetiological factors and geographical distribution of $\ldots \quad \ldots \quad \quad \ldots \quad \ldots$

Tabetic optic atrophy, therapeutic measures in

Tarsitis, syphilitic, of polypoid

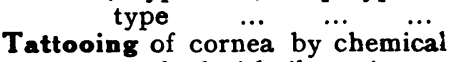
method with silver nitrate. gold chloride and platinum $\begin{array}{lllll}\text { chloride } & . . & \ldots & \ldots & 663\end{array}$ 
Trachoma, American India $\ddot{n}$, cultures of microorganism isolated from cases of, induction of chronic granular conjunctivitis in macacus rhesus and chimpanzee by ... $\ldots$... among Indians of the South

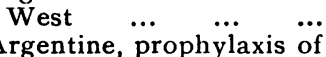

in Syria and Lebanon, frequency, clinical forms, aetiological factors and geographical distribution of $\ldots . \quad \ldots$... $\quad \ldots$

intravenous injection of cop-

-like condition in monkeys, experimental production of $\ldots$... $\quad \ldots$... prophylaxis and treatment of $\ldots \quad \ldots \quad \ldots . \quad \ldots$

Tuberculin treatment, episcleritis

Tuberculosis, relation of uveoparotid fever to... $\ldots$

Tumour of choroid, early symptoms of $\quad . . \quad \ldots$

Tumours, intraocular, latent, juxta - papillary leucosarcoma, with iridocyclitis $\ldots . \quad \ldots \quad \ldots$

Ulcer, hypopyon, aetiology and treatment of $\quad \ldots$.... Ulceration of cornea, treatment

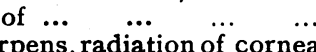
Ulcusserpens, radiation of cornea
with ultra-violet light in with ultra-violet light in of ophthalmic disease ... 289 local phototherapy $\quad$... 353 radiation of cornea with, especially in ulcus

$\begin{array}{cccr}\text { serpens } & \ldots & \ldots & 49 \\ \text { Ultra-violet rays, value of } & \ldots & & 228\end{array}$

Uveitis, unilateral chronic anterior, in children $\quad .$.

Uveo-parotid fever and its relation to tuberculosis $\quad \ldots \quad 420$

van der Hoeve's syndrome (blue sclerotics - fragility of bones - deafness) two cases of $\quad \cdots \quad \quad \cdots \quad \cdots$

Vascular naevi, radium in treat-

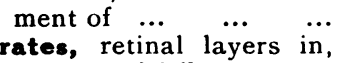
process of differentiation

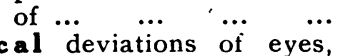

Vertical deviations of eyes,
latent, diagnosis of, by
use of prolonged mon-
ocular occlusion
Vesicles and cysts on surface

Vertical deviations of eyes,
latent, diagnosis of, by
use of prolonged mon-
ocular occlusion
Vesicles and cysts on surface

Vertical deviations of eyes,
latent, diagnosis of, by
use of prolonged mon-
ocular occlusion
Vesicles and cysts on surface and in substance of cornea, formation of $\quad \ldots \quad 660$

Vision, field of, different types of $\begin{array}{llll}\text { defects } \text { of... } \quad \ldots & \ldots & 343\end{array}$

in last weeks of pregnancy, examination of $\quad$...

Visual acuity, effect of viewıng motion pictures on ...

Visualization of lacrymal passages by use of lipiodol

Vitreous, simultaneous familial changes in, in hitherto unknown type of familial, presenile subcapsular cataract ... ... ...

von Graefe. Albrecht, centenary of $\quad \ldots \quad \ldots \quad$... 531

Warner's operation for cataract 259

Webster's operation for entro-

Wells, William Charles, M.D., F.R.S. (1757-1817) $\quad$... 561

Wound-fixation for intracapsular extraction of catar$\begin{array}{lllll}\text { act } & \ldots & \ldots & \ldots & 411\end{array}$

Xerosis of conjunctiva and cornea, pathologv of $\quad \begin{array}{lll} & \ldots & 381\end{array}$

$\mathbf{X}$-rays in treatment of glioma of $\begin{array}{lllll}\text { retina } & \ldots & \ldots & \ldots & 41\end{array}$

Zinc ionisation in ophthalmic $\begin{array}{lllll}\text { work } & \ldots & \ldots & \ldots & 608\end{array}$

Zinn, zonule of : development, structure, topography, and physiology ... $\quad . .5 \quad 538$ 